\title{
Anti-Metastatic Propensity of Biscoumarin Scaffold Synthesized Under Catalyst Free Aqueous Phase Microwave Irradiation
}

\author{
Shazia Muzaffar Banday, ${ }^{1}$ Asif Amin, ${ }^{2}$ Shabnum Bashir, ${ }^{1}$ Raies A. Qadri, ${ }^{2}$ Khaliquz Zaman Khan, ${ }^{1}$ Masood Ahmad Rizvi ${ }^{1, *}$
}

\author{
1 Department of Chemistry, University of Kashmir, Hazratbal, Srinagar, Jammu \& Kashmir, 190006, India \\ 2 Department of Biotechnology, University of Kashmir, Hazratbal, Srinagar, Jammu \& Kashmir, 190006, India \\ * Corresponding author's e-mail address: masoodku2@gmail.com \\ RECEIVED: April 25, 2017 * REVISED: August 17, 2017 * ACCEPTED: October 14, 2017
}

\begin{abstract}
An environmentally benign, catalyst free, aqueous phase, microwave assisted method for the synthesis of biscoumarin derivatives using 4-hydroxycoumarin and different aldehydes is reported. The comparative investigation of the same synthetic methodology under conventional refluxing, domestic and scientific programmable microwave synthesizer has been attempted for the purpose of comparing the reaction performance in terms of \% yield, reaction time, reproducibility and reaction control. In addition to the increased yields and attenuated reaction times for biscoumarin synthesis, the difficulty of reaction control and result reproducibility usually encountered with domestic microwave ovens have been addressed through an optimized synthetic methodology using microwave synthesizer. Screening bioactive compounds for their propensity towards inhibition of cancer metastasis is a must step in advancement of cancer chemotherapy. The synthesized biscoumarin scaffold was investigated for inhibitory metastatic activity against human lung carcinoma cell line, A549 through in vitro wound healing and invasion assays. The biscoumarin scaffold was found to possess an effective anti-proliferative activity. It was also found to be efficient in ablating the migration and invasiveness of these cells under in vitro conditions.
\end{abstract}

Keywords: biscoumarin, 4-hydroxycoumarin, aqueous phase, microwave synthesizer, catalyst-free, antiproliferative activity, migration and invasion, human lung carcinoma cell line, A549.

\section{INTRODUCTION}

C OUMARINS are a class of oxygen heterocycle compounds consisting of a benzene ring fused to a six membered lactone ring. In plants, a number of fungi species transform coumarin to dicoumarol which is a natural anticoagulant that functions as vitamin $\mathrm{K}$ antagonist. Dicoumarol, chemically designated as [3,3'methylenebis(4-hydroxy-2H-chromen-2-one)], (Scheme 1) is a potent anticoagulant and acts by inhibiting the synthesis of vitamin K-dependent clotting factors in the liver. Compounds with dicoumarol type ring system are referred to as biscoumarins and can be obtained by the reaction of 4hydroxycoumarin with various aldehydes. Compounds with biscoumarin scaffold have widespread biological properties like enzyme inhibitors, anti-infectives (antibacterial, antifungal, antiviral, anthelmintic) and insecticidal activities. Besides, these are also known to have antioxidant, hypnotic and spasmolytic activities. ${ }^{[1-7]}$ Furthermore these have also been found to be potent anti-HIV agents being active against HIV-1 integrase. ${ }^{[8,9]}$ The biscoumarin derivatives were observed to have a synergistic effect with taxol towards the cell division inhibition activity of sea urchin embryos. ${ }^{[10]}$ Recently, it was found that biscoumarins can induce cell killing and oxidative stress in pancreatic cancer cells via the inhibition of NADPH : quinone oxidoreductase (NQO1). ${ }^{[11]}$

Keeping view of the dominance among natural pharmacophores, coupled with their attractive pharmaceutical potency, the synthesis of biscoumarins continues to be an active area in synthetic organic chemistry. Biscoumarins have been synthesized by the condensation of 4-hydroxycoumarin with aldehydes in the presence of a range

(c) Br $\mathbf{B Y}$ This work is licensed under a Creative Commons Attribution 4.0 International License. 
of catalysts like $\mathrm{Et}_{2} \mathrm{AlCl}^{,[12]}$ heteropolyacids, ${ }^{[13]}$ tetrabutyl ammonium hexatungstate $[\mathrm{TBA}]_{2}\left[\mathrm{~W}_{6} \mathrm{O}_{19}\right]^{[14]}$ silica-supported sodium hydrogen sulphate or Indion 190 resin, [15] and nickel nanoparticles.[16,17] Some of the environment friendly methods like solid-state reactions, ${ }^{[18]}$ thermal solvent-free conditions, ${ }^{[19]}$ and sonochemical conditions, ${ }^{[20]}$ have also been reported for synthesis of some biscoumarins. Most of these synthetic methodologies suffer drawbacks like narrow substrate scope, strong acidic conditions, need of metal catalysts, toxic reagents / catalysts / solvents, longer reaction time with compromising \% yields and laborious work-up procedures.

Therefore, environmentally benign, solvent-less, catalyst-free, cost-effective and efficient protocols for the synthesis of these compounds are still desirable. From green chemistry point of view, water is a uniquely advantageous, inherently safe and environmentally benign solvent. Many aqueous phase synthesis of biscoumarins in presence of catalysts such as molecular iodine, ${ }^{[21]}$ tetrabutyl ammonium bromide (TBAB), ${ }^{[22]}$ sodium dodecyl sulphate (SDS), ${ }^{[23]}$ phosphotungstic acid, ${ }^{[24]}$ and zinc(proline) ${ }_{2},{ }^{[25]}$ have been recently reported. However, all these reported aqueous phase synthetic methods require the use of catalysts, which in most cases have to be synthesized separately under non benign reaction conditions. Besides the use of catalyst brings the additional steps in the workup making the methodology tedious and cost intensive. Thus in continuation of our efforts in developing newer synthetic methodologies, ${ }^{[26-31]}$ we herein, report the catalyst free synthesis of biscoumarins using microwave irradiation in aqueous ethanol as solvent. In light of the reported anticancer activity of biscoumarins, we attempted to explore the effect of biscoumarin scaffold towards the metastatic behavior of human lung carcinoma cells. Our observations suggest that biscoumarin scaffold can inhibit the migration and invasion of lung carcinoma cells in a dose dependent manner.

\section{RESULTS AND DISCUSSION}

\section{Chemistry / Synthesis}

The reaction of 4-hydroxycoumarin with aldehydes in pure water under catalyst free conditions gives poor or no yields due to the limited aqueous solubility of reactants. An enhancement in the reaction yields was observed on addition of little ethanol to the reaction mixture. So, we attempted to optimize the solvent system for a satisfactory \% yield and reaction conditions. The reaction of 4-hydroxycoumarin (1) and benzaldehyde (2b) was selected as model reaction for optimization and was attempted under different volume ratios of water and ethanol through $70^{\circ} \mathrm{C}$ reflux on a water bath for upto 9 hours. The solvent ratio of $2: 1\left(\mathrm{H}_{2} \mathrm{O}: \mathrm{EtOH}\right)$ was found to give the maximum \% yield for a 2:1 molar ratio

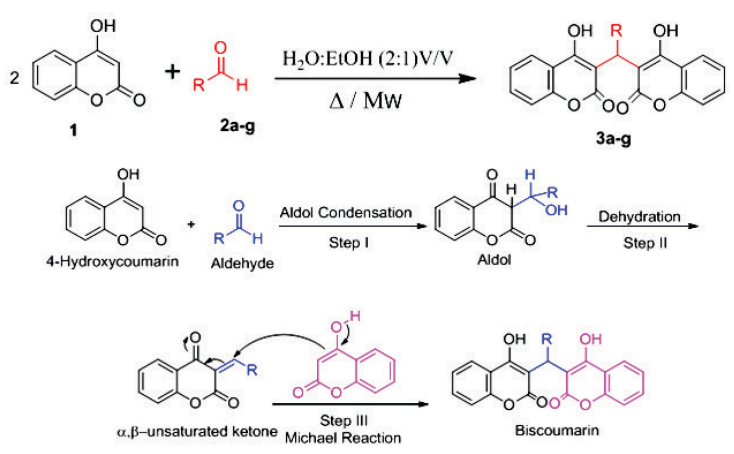

Scheme 1. Reaction scheme of biscoumarin synthesis under catalyst free aqueous phase microwave irradiation.

of 4-hydroxycoumarin (1) and benzaldehyde (2b). A library of seven biscoumarin derivatives was synthesized by the reaction of 4-hydroxycoumarin(1) with different aldehydes (2a-g) under the similar reaction conditions (Scheme 1) with their \% yields in Table 1.

Motivated with improved reaction yields via solvent optimization, we attempted to target the reaction completion time through the synthesis of biscoumarins under microwave irradiation. The microwave irradiation under similar reaction conditions, made the synthetic reaction more \% yield efficient, besides, the reaction completion time got reduced to minutes from several hours of refluxing under conventional reaction conditions. We initially used SHARP R-21LC model (1000W) domestic microwave oven. The reactions were carried out in the form of successive heating cooling cycles of 30 seconds heating/irradiation in sealed teflon tubes followed by 2 min of cooling in order to prevent the excess of pressure from developing inside the tube. The comparative results of conventional refluxing and microwave heating are summarized in Table 1. However due to the inherent limitations of uncontrolled reaction conditions (no accurate temperature and pressure measurements) coupled with superheating and hot spot generation in the microwave heating of domestic ovens, the synthetic results were not very reproducible.

Thus, in order to develop a reproducible microwave assisted methodology for the synthesis of biscoumarins in aqueous ethanol solvent, the reaction of 4-hydroxycoumarin (1a) with benzaldehyde (2b) was carried out at different temperatures and irradiation levels (temperature hold times) in a single heating cycle over Anton Paar Monowave 300 synthesizer. The temperature of $150^{\circ} \mathrm{C}$ and hold time of three minutes were found to be optimum for the best synthetic results and were thus employed for all other reactions. It was observed that the reactions proceed in a controlled manner with greater reproducibility and better yields when carried out under microwave irradiation in Anton Paar monowave 300 synthesizer (Table 2). 
Table 1. A comparative account of the Biscoumarin synthesis under conventional refluxing and microwave irradiation.(a)

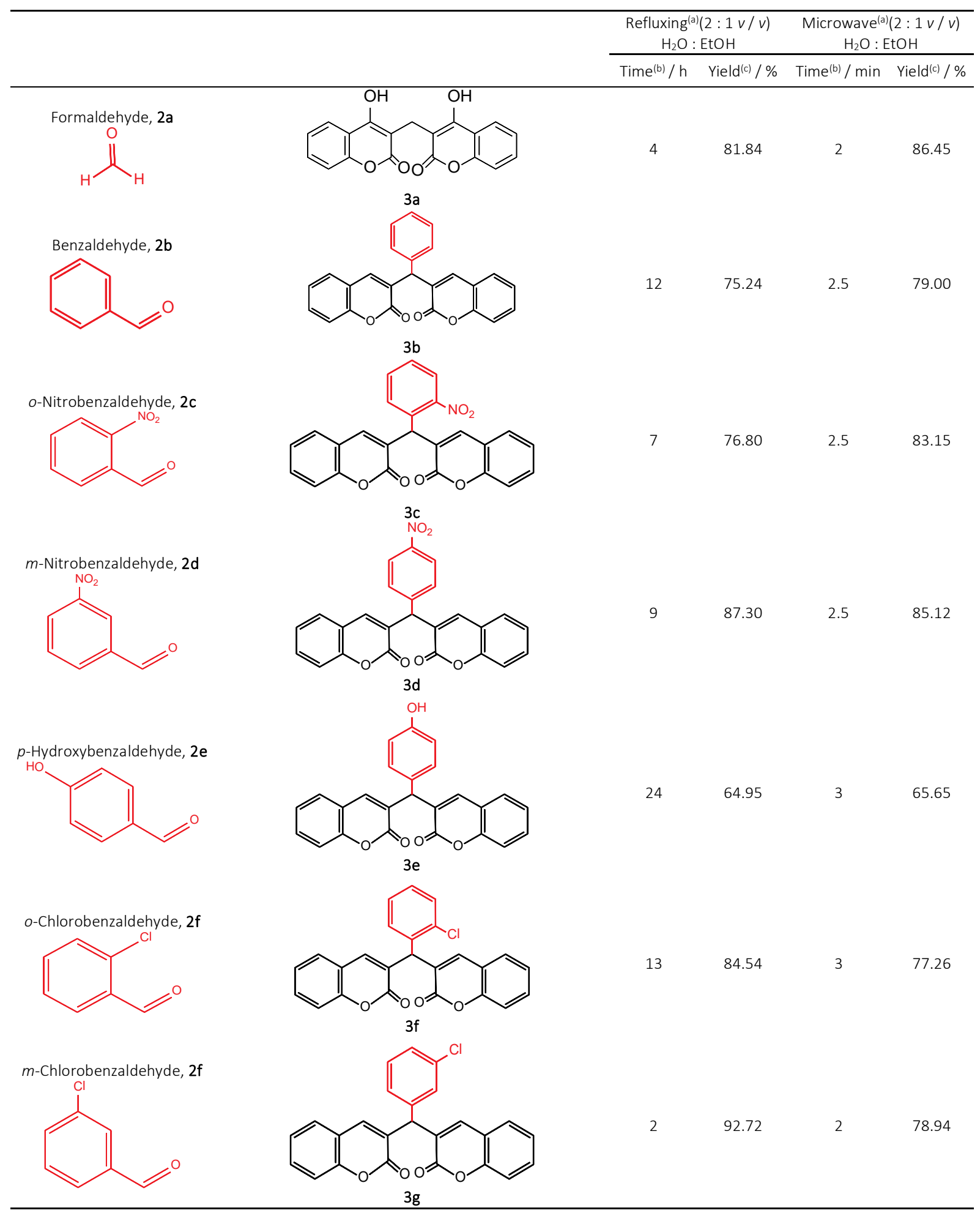

(a) Reaction conditions: The reactions were carried out at intervals of 30 s in sealed teflon tubes in order to prevent the excess of pressure from developing inside the tube.

(b) Reaction progress monitored by TLC.

(c) All yields refer to the isolated products. 
A comparison of the reactions of 4-hydroxycoumarin (1a) with aldehydes (2a-g) under microwave irradiation of Anton Paar Monowave synthesizer using 2: 1 water-ethanol mixture and only ethanol as solvent are shown in Table 2. From Table 2, it is evident that $2: 1$ volume ratio of water to ethanol for same irradiation level (hold time) in case of all the seven reaction samples has produced double the $\%$ yields than in pure ethanol suggesting that 2:1 water ethanol is a better solvent system for the synthesis of biscoumarins under microwave conditions. The microwave heating ability of a solvent depends on its dielectric properties. The capability of a solvent to transform electromagnetic energy into heat under a given set of conditions (frequency and temperature) is expressed in terms of loss factor i.e. $\tan \delta .=\varepsilon^{\prime \prime} / \varepsilon^{\prime}$, where $\varepsilon^{\prime \prime}$ is the dielectric loss, which is indicative of the efficiency with which electromagnetic radiation can be converted into heat, and $\varepsilon^{\prime}$ is the dielectric constant which indicates the ability of molecules to be polarized by the electric field. The solvent system with a high $\tan \delta$ value shows efficient absorption and, consequently rapid heating. The corresponding values of dielectric properties for water and ethanol are as shown:

\begin{tabular}{lcrr} 
& $\varepsilon^{\prime}$ & \multicolumn{1}{c}{$\varepsilon^{\prime \prime}$} & $\tan \delta$ \\
Ethanol & 24.3 & 22.866 & 0.941 \\
Water & 80.4 & 9.889 & 0.123
\end{tabular}

It is evident that ethanol has a lower dielectric constant but a higher dielectric loss than water. Due to the higher value of loss factor ( $\tan \delta=0.941$ ), the reactions in ethanol are expected to be more efficient under microwave irradiation than in water with a lower loss factor $(\tan \delta=$
0.123). However, the reactions were observed to be more efficient (with higher \% yields) in $2: 1 v / v$ water-ethanol mixture than in pure ethanol under microwave irradiation in Antan Parr microwave synthesizer. This interesting observation can be explained on the basis of the different microwave heating behaviour of pure ethanol and water ethanol mixture with regard to the heat generation and dielectric loss over radiation time. ${ }^{[32,33]}$ Almost all solvents show a strong influence of temperature on dielectric properties. Near to the boiling point, the solvent density decreases leading to the decrease in dielectric properties and hence lowering of the loss factor and consequently attenuated heat generation. The higher loss factor of ethanol allows an initial rapid increase in temperature Figure 1a, however, upon reaching the selected reaction temperature, microwave power decreases or shuts off completely in order to maintain the selected bulk temperature without exceeding it leading to the decrease in heat generation with time.

Water due to lower loss factor allows a slow initial raise in temperature Figure $1 \mathrm{~b}$ but due to its high boiling point allows relatively lesser decrease in its dielectric properties compared to ethanol. Moreover, as can be seen from the Figure 1, the microwave lamp continues to power the reaction mixture for more time in case of water ethanol system. Besides the initial pressure of the reaction system is very steep in case of water ethanol system compared to pure ethanol as can be seen from Figure1. Due to these underlying effects, the $2: 1$ water-ethanol mixture turns out to be more efficient solvent system under microwave irradiation over pure ethanol in converting electromagnetic radiation to heat.
Figure 1a (Reaction in ethanol)

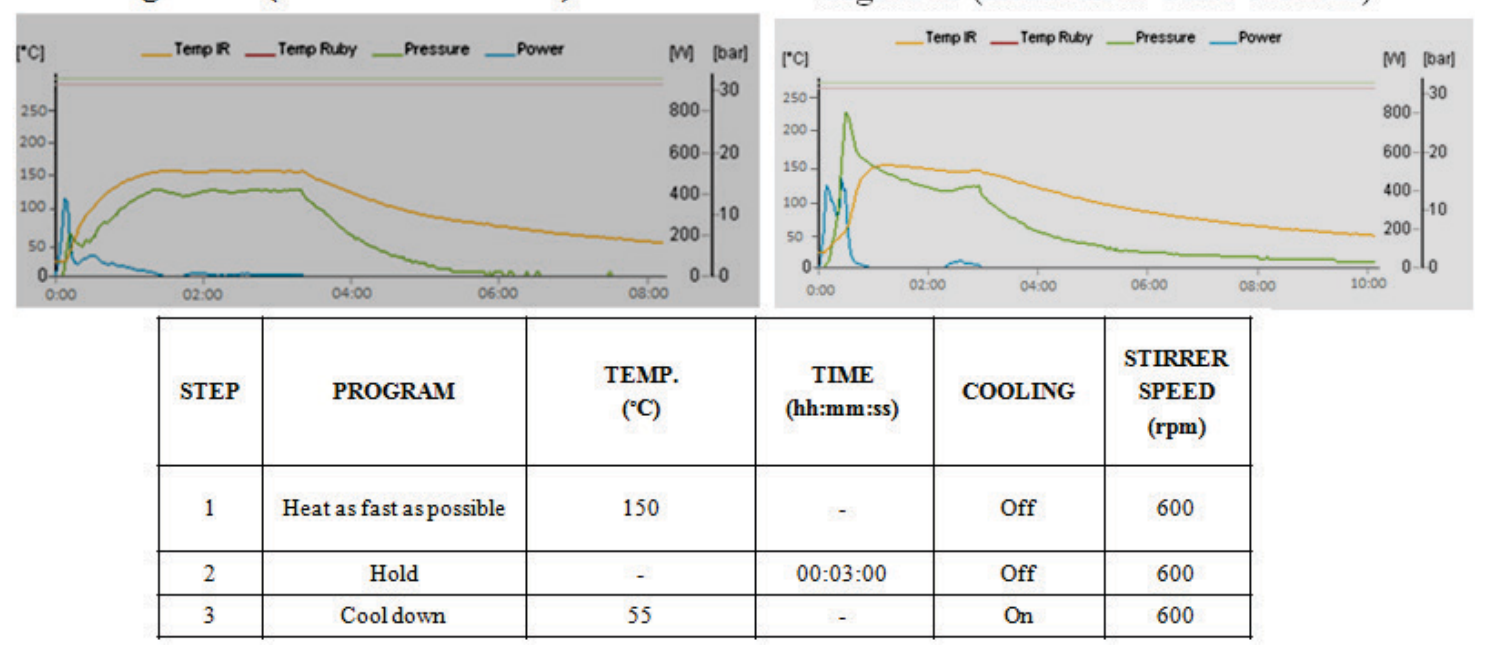

Figure 1. The optimized microwave irradiation programme for the biscoumarin synthesis with pure ethanol and water-ethanol solvent system in Anton Paar Monowave 300 Synthesizer. 
Table 2. \% yields comparison of biscoumarins ( $3 \mathrm{a}-\mathrm{g}$ ) under microwave conditions of commercial Microwave Synthesis Reactor using $\mathrm{H}_{2} \mathrm{O}-\mathrm{EtOH}(2: 1$ ratio) and EtOH only as solvent.

\begin{tabular}{|c|c|c|c|c|c|c|c|}
\hline & \multirow{3}{*}{ S. No. } & \multirow{3}{*}{ Aldehydes } & \multirow{3}{*}{ Time / min } & \multicolumn{4}{|c|}{$\mathrm{YIELD}^{(c)} / \%$} \\
\hline & & & & \multicolumn{2}{|c|}{ Domestic Microwave $e^{(a)}$} & \multicolumn{2}{|c|}{ Microwave Synthesis Reactor ${ }^{(b)}$} \\
\hline & & & & EtOH only & $\mathrm{H}_{2} \mathrm{O}-\mathrm{EtOH} 2: 1(v / v)$ & EtOH only & $\mathrm{H}_{2} \mathrm{O}-\mathrm{EtOH} 2: 1(v / v)$ \\
\hline & 1. & Formaldehyde & 2.0 & 36.16 & 86.45 & 46.57 & 88.54 \\
\hline & 2. & Benzaldehyde & 2.5 & 74.02 & 79.00 & 46.11 & 93.08 \\
\hline & 3. & o-Nitrobenzaldehyde & 2.5 & 65.31 & 83.15 & 45.62 & 82.38 \\
\hline & 4. & m-Nitrobenzaldehyde & 2.5 & 79.97 & 85.12 & 46.06 & 86.65 \\
\hline & 5. & p-Hydroxybenzaldehyde & 3.0 & 56.89 & 65.65 & 48.59 & 85.86 \\
\hline & 6. & o-Chlorobenzaldehyde & 3.0 & 48.26 & 77.26 & 47.36 & 83.53 \\
\hline & 7. & $m$-Chlorobenzaldehyde & 2.0 & 76.93 & 78.94 & 48.04 & 85.21 \\
\hline \multicolumn{8}{|c|}{ ) SHARP R-21LC model (1000W). } \\
\hline \multicolumn{8}{|c|}{ b) Anton Paar Monowave 300} \\
\hline
\end{tabular}

\section{Biology}

\section{BISCOUMARIN SCAFFOLD INHIBITS THE PROLIFERATION OF LUNG CARCINOMA CELLS}

Tumour metastasis, involving movement of cancerous cells to healthy organs, is a major contributor to the death in cancer patients. Blocking the cancer cell proliferation can prevent the cancer metastasis. Thus screening bioactive compounds for their propensity towards inhibition of cancer cell proliferation is a must step in advancement of cancer chemotherapy. Towards this direction, we attempted to evaluate the effect of biscoumarin on the

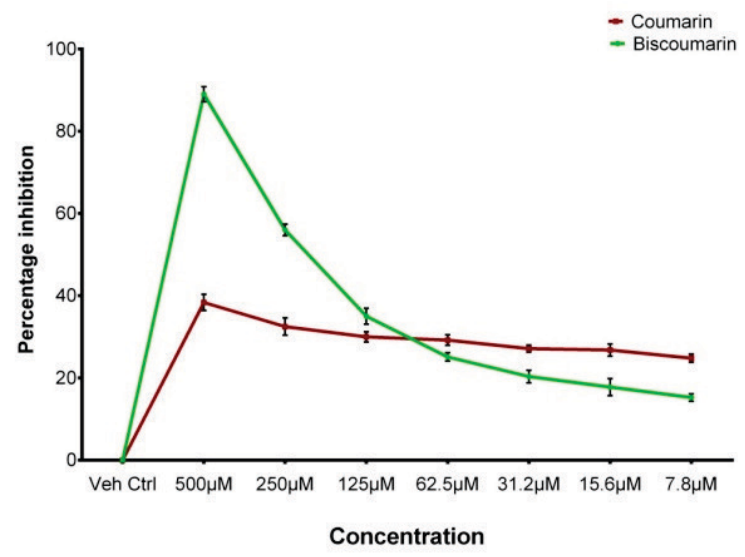

Figure 2. Anti-proliferative effect of biscoumarin on lung carcinoma cells. A549. Cells were treated with the indicated concentrations (500-7.8 $\mu \mathrm{M}$ ) of coumarin and biscoumarin respectively. After $24 \mathrm{~h}$, the inhibition of cell proliferation was determined by MTT assay. Data represented as mean $\pm S D$ of results from three independent experiments. proliferation of human lung adenocarcinoma (A549) cancer cell line. The A549 cell line was treated with biscoumarin which was followed by MTT monitoring assay. It was observed that the biscoumarin scaffold showed a distinctive effect on the proliferation of A549 cells in comparison to coumarin. This can be attributed to the differences in their physicochemical properties, that determine the interaction with biotargets, bioavailability and the ability to pass through biomembranes for a significant action. ${ }^{[34]}$ Biscoumarins, due to their increased hydrophobicity and double the number of biologically active $\mathrm{OH}$ and $\mathrm{C}=\mathrm{O}$ groups than coumarins, indeed should betterly interact with biological targets and should also have higher bioavailability. The observed results demonstrate that the proliferative abilities of A549 cells decreased in a dose-dependent manner on treatment with biscoumarin scaffold with IC50 value of $214.28 \mu \mathrm{M}$. Our results are in conformity with those previously observed by Keerthy et al., in hepatocellular carcinoma where it has been shown that a biscoumarin significantly inhibits the proliferation of the HCC cell lines in a dose and time dependent manner. ${ }^{[35]}$ Collectively, these primary results led us to test biscoumarin scaffold further for its antimetastatic properties.

\section{BISCOUMARIN SCAFFOLD ABLATE THE MIGRATION AND INVASION OF LUNG CARCINOMA CELLS}

Migration and invasiveness are important to the multistep process of carcinogenesis and constitute important targets for cancer chemoprevention. We, therefore, attempted to evaluate whether biscoumarin could affect such metastatic properties of A549 cell line. A549 cells were grown to subconfluency, wounded and then treated with different subtoxic concentrations of biscoumarin. As shown in Figure 3, 


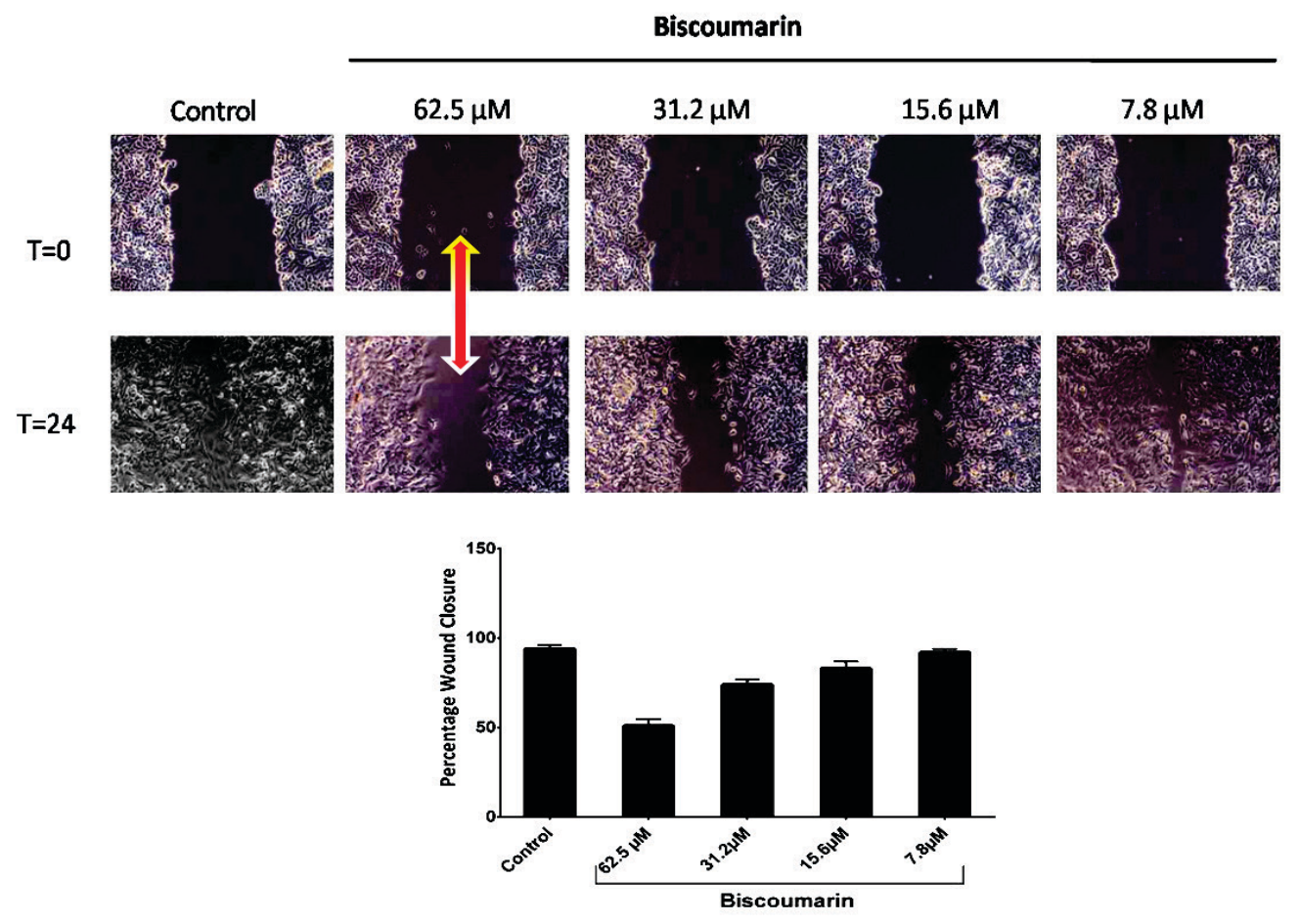

Figure 3. Wound healing assay of A549 cell line showing inhibition of the metastasis in lung carcinoma cells. Cells were grown to confluency, wounded and then grown in presence of mentioned concentrations of biscoumarin for $24 \mathrm{~h}$. The wounded areas were photographed at zero hour $(T=0)$ and then after $24 \mathrm{~h}(T=24)$. The the yellow and white arrow heads of red arrow indicate that at the sub toxic concentration of $62.5 \mu \mathrm{M}$. Biscoumarin has inhibited $50 \%$ of wound healing while at $7.8 \mu \mathrm{M}$ the $\%$ wound healing is similar to that in control suggesting dose dependent in vitro anti-metastatic property of biscoumarin scaffold.

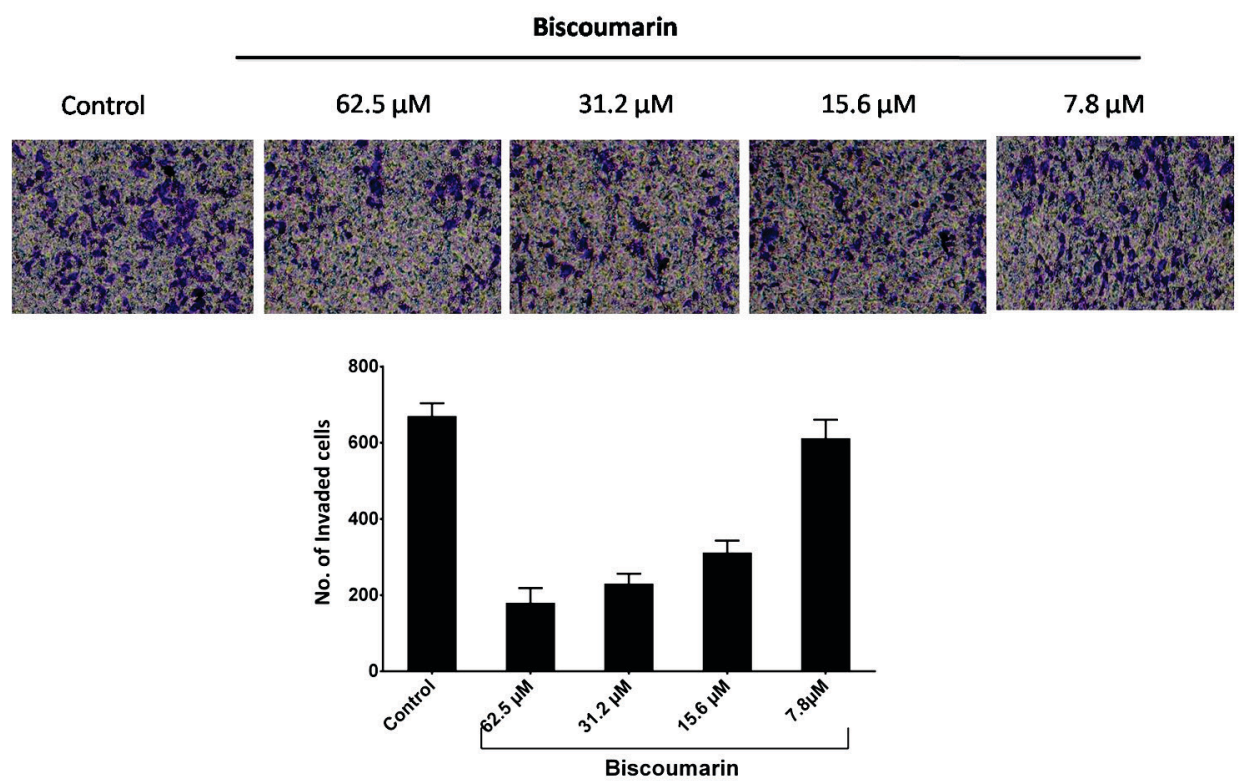

Figure 4. Invasion assay of A549 cell line showing inhibition of the metastasis in lung carcinoma cells. A549 cells were placed in matrigel coated transwell chambers in presence of indicated concentrations of biscoumarin and allowed to invade. After $24 \mathrm{~h}$, the invaded cells were fixed, stained, photographed and counted. Data represented as mean \pm SD of results obtained from at least three independent experiments for both the assays. 
biscoumarin significantly overcame the ability of A549 cells to migrate across the wounded area in a dose dependent manner, thus pointing at their role in inhibiting the pathway(s) that lead to cancer cell migration. Using $7.8 \mu \mathrm{M}$ concentration led to the closure of about $80 \%$ of the wound, treatment with 15.6, 31.2 and $62.5 \mu \mathrm{M}$ concentrations of biscoumarin inhibited the wound healing to about $70 \%, 60 \%$ and $50 \%$ respectively. These findings were further supported by transwell invasion assay. A549 cells were cultured in the absence or presence of different sub-toxic concentrations of biscoumarin and allowed to migrate through matrigel coated transwell chambers. It was observed that the biscoumarin significantly inhibited the invasion of A549 cells in a dose dependent manner in comparison to control as shown in Figure 4. The treatment with highest concentration of biscoumarin led to the inhibition of invasiveness of $A 549$ cells by about 5 times. These findings depict that biscoumarin scaffold inhibits the motility of lung carcinoma cells, thus pointing at its role in inhibiting the pathway(s) that lead to cancer cell migration and invasion. It furthers points at the possibility of the biscoumarin scaffold to act as an inhibitor of pro-metastatic protein(s) activated in these cells, thereby mediating its anti-metastatic effects.

\section{EXPERIMENTAL}

\section{Chemistry}

All the chemicals used were of Sigma and Merck Chemicals (India) make. Thin layer chromatography was performed using TLC Silica gel $60 \mathrm{~F}_{254}$ Aluminium sheets with the hexane-ethyl acetate $(8: 2)$ solvent system. The TLC spots were located by means of UV chamber under both short (254 nm) and long (365 nm) UV light. Elemental analyses were performed on Perkin Elmer 2400 Series II CHN Elemental Analyzer). Infrared spectra were recorded on a Perkin Elmer-Spectrum RX-FTIR instrument. ${ }^{1} \mathrm{H}-\mathrm{NMR}$ spectra were recorded on a Bruker Avance II $400 \mathrm{MHz}$ NMR Spectrometer using $\mathrm{CDCl}_{3}$ or DMSO- $d_{6}$ as solvent and tetramethylsilane (TMS) as internal standard. Mass Spectra were obtained on Waters Micromass Q-Tof Micro instrument. The microwave ovens used were a domestic, multimode SHARP R-21LC model and a programmable microwave synthesizer Anton Paar monowave 300. The melting points were taken in open capillaries using a Perfit Melting Point apparatus and are uncorrected.

\section{PROCEDURE FOR SYNTHESIS OF BIS(4-HYDROXY-2H- CHROMEN-2-ONES) 3a-g (CONVENTIONAL REFLUXING CONDITIONS)}

A mixture of 4-hydroxycoumarin (1) $(0.648 \mathrm{~g}, 4 \mathrm{mmol})$ and aldehydes $\mathbf{2 a - g}(2 \mathrm{mmol})$ in $2: 1 \mathrm{v} / \mathrm{v}$ water-ethanol mixture was taken in a $25 \mathrm{~mL}$ round-bottomed flask and refluxed around $70^{\circ} \mathrm{C}$ over a water bath. The progress of reaction was continuously monitored by thin layer chromatography. After the completion of reaction as evidenced from TLC, the mixture was cooled to room temperature and the product was filtered under suction, washed with ethanol and dried. The crude sample was re-crystallized from ethanol chloroform (7:3) mixture.

\section{PROCEDURE FOR SYNTHESIS OF BIS(4-HYDROXY-2H- CHROMEN-2-ONES) 3a-g (DOMESTIC MICROWAVE CONDITIONS)}

A mixture of 4-hydroxycoumarin (1) (0.648 g, $4 \mathrm{mmol}$ ) and aldehydes $2 \mathrm{a}-\mathrm{g}(2 \mathrm{mmol})$ in $3.5 \mathrm{~mL}$ of $2: 1 \mathrm{v} / \mathrm{v}$ waterethanol mixture was taken in a sealed teflon-tube and irradiated in a domestic microwave oven. The microwave heating was done in the form of a sequence of heating cooling cycles to avoid the pressure build up till completion of reaction time. Each irradiation cycle was of $30 \mathrm{~s}$ duration at an average power of $1000 \mathrm{~W}$ and was followed by a resting period of two minutes to avoid overheating and pressure build up. The optimized heating cooling cycles were continued till the completion of reaction as evidenced from TLC. The reaction mixture was finally cooled to room temperature and the product was filtered under suction, washed with ethanol and dried.

PROCEDURE FOR SYNTHESIS OF BIS(4-HYDROXY-2HCHROMEN-2-ONES) 3a-g (MICROWAVE CONDITIONS USING ANTON PAAR MICROWAVE REACTOR/SYNTHESIZER)

A mixture of 4-hydroxycoumarin (1) $(0.648 \mathrm{~g}, 4 \mathrm{mmol})$ and aldehydes $2 \mathrm{a}-\mathrm{g}(2 \mathrm{mmol})$ in $3.5 \mathrm{~mL}$ of solvent was taken in a $10 \mathrm{~mL}$ borosilicate glass vial (G10) sealed with a PTFEcoated silicone septum closed with a snap cap and irradiated in a Monowave 300 at $150^{\circ} \mathrm{C}$ with heat as fast as possible heating option and at a stirring speed of $600 \mathrm{rpm}$ for the three minutes or the selected hold times. The reactions were programmed to a cooling temperature of $55^{\circ} \mathrm{C}$. After the completion of reaction, the product was filtered, washed with ethanol and dried to obtain the \% yield. The spectroscopic characterization of the synthesized compounds was done by FTIR as $\mathrm{KBr}$ discs, and ${ }^{1} \mathrm{H}$ and ESI-MS.

3,3-Methylenebis(4-hydroxy-2H-chromen-2-one) (3a) White crystalline solid, $\mathrm{mp} 278-280^{\circ} \mathrm{C}$. IR spectrum $(\mathrm{KBr})$, $v / \mathrm{cm}^{-1}$ : 3062 (O-H), 2904, 2800 (C-H), 1639, 1599 (C=O), 1501, $1453(\mathrm{C}=\mathrm{C}), 769,750$ (C-H). ${ }^{1} \mathrm{H}$ NMR spectrum (400MHz, DMSO- $\left.d_{6}\right), \delta /$ ppm: $3.82\left(2 \mathrm{H}, \mathrm{s}, \mathrm{CH}_{2}\right) ; 7.33-7.95$ $(8 \mathrm{H}, \mathrm{m}, \mathrm{H} \mathrm{Ar}) ; 8.20(2 \mathrm{H}, \mathrm{s}, \mathrm{OH})$. Mass spectrum (ESI): Found, $m / z: 334.8$ [M-2H]-. $\mathrm{C}_{19} \mathrm{H}_{10} \mathrm{O}_{6}$. Calculated, $m$ / z: 334.2.

3,3-Benzylidenebis(4-hydroxy-2H-chromen-2-one) (3b) White crystalline solid, $\mathrm{mp} 226-228^{\circ} \mathrm{C}$. IR spectrum $(\mathrm{KBr})$, $v / \mathrm{cm}^{-1}$ : 3064, 3023 (O-H), 1654, 1618 (C=O), 1566, 1496, 
$1450(\mathrm{C}=\mathrm{C}), 757(\mathrm{C}-\mathrm{H}) .{ }^{1} \mathrm{H}$ NMR spectrum $\left(400 \mathrm{MHz}, \mathrm{CDCl}_{3}\right)$, $\delta /$ ppm: $6.09(1 \mathrm{H}, \mathrm{s}, \mathrm{CH}) ; 7.20-8.07$ (13H, m, H Ar); 11.30 $(1 \mathrm{H}, \mathrm{s}, \mathrm{OH}) ; 11.53(1 \mathrm{H}, \mathrm{s}, \mathrm{OH})$. Mass spectrum (ESI): Found, $m / z: 410.9[\mathrm{M}-2 \mathrm{H}]^{-} . \mathrm{C}_{25} \mathrm{H}_{14} \mathrm{O}_{6}$. Calculated, $m$ / z: 410.3.

\section{3,3-(2-Nitrobenzylidene)-bis(4-hydroxy-2H-chromen-2- one) (3c)}

Light yellow crystalline solid, $\mathrm{mp} 196-198^{\circ} \mathrm{C}$. IR spectrum $(\mathrm{KBr}), v / \mathrm{cm}^{-1}$ : 3078, $3022(\mathrm{O}-\mathrm{H}), 1655,1616$ (C=O), 1565, 1495, $1454(\mathrm{C}=\mathrm{C}), 1525,1352\left(\mathrm{NO}_{2}\right), 763(\mathrm{C}-\mathrm{H}) .{ }^{1} \mathrm{H}$ NMR spectrum $\left(400 \mathrm{MHz}, \mathrm{DMSO}-d_{6}\right), \delta / \mathrm{ppm}: 6.71(1 \mathrm{H}, \mathrm{s}, \mathrm{CH})$; 7.17-7.95 (12H, m, H Ar); $8.18(2 \mathrm{H}, \mathrm{s}, \mathrm{OH})$. Mass spectrum (ESI): Found, $m / z$ : 455.9 [M-2H]-. $\mathrm{C}_{25} \mathrm{H}_{13} \mathrm{NO}_{8}$. Calculated, $m / z: 455.3$.

\section{3,3-(3-Nitrobenzylidene)-bis(4-hydroxy-2H-chromen-2- one) (3d)}

Light yellow crystalline solid, $\mathrm{mp} 230-232{ }^{\circ} \mathrm{C}$. IR spectrum (KBr), v / cm ${ }^{-1}$ : 3077, $3022(\mathrm{O}-\mathrm{H}), 1663,1610$ (C=O), 1566, 1496, 1449 (C=C), 1530, $1347\left(\mathrm{NO}_{2}\right), 764(\mathrm{C}-\mathrm{H}) .{ }^{1} \mathrm{H}$ NMR spectrum $\left(400 \mathrm{MHz}, \mathrm{DMSO}-d_{6}\right), \delta / \mathrm{ppm}: 6.58(1 \mathrm{H}, \mathrm{s}, \mathrm{CH})$; 7.34-8.08 (12H, m, H Ar); $8.86(2 \mathrm{H}, \mathrm{s}, \mathrm{OH})$. Mass spectrum (ESI): Found, $m$ / z: $455.9[\mathrm{M}-2 \mathrm{H}]^{-} . \mathrm{C}_{25} \mathrm{H}_{13} \mathrm{NO}_{8}$. Calculated, $m / z: 455.3$.

\section{3,3-(4-Hydroxybenzylidene)-bis(4-hydroxy-2H-chromen- 2-one) (3e)}

White crystalline solid, $\mathrm{mp} 208-210^{\circ} \mathrm{C}(\mathrm{EtOH})$. IR spectrum (KBr), v / cm ${ }^{-1}$ : 3356, 3076, 3020 (O-H), 1648, 1616 (C=O), 1565, 1512, $1441(\mathrm{C}=\mathrm{C}), 762(\mathrm{C}-\mathrm{H}) .{ }^{1} \mathrm{H}$ NMR spectrum (400MHz, $\left.\mathrm{CDCl}_{3}\right), \delta / \mathrm{ppm}: 6.01(1 \mathrm{H}, \mathrm{s}, \mathrm{CH}) ; 6.74-8.03(13 \mathrm{H}$, $\mathrm{m}, \mathrm{H} \mathrm{Ar}) ; 11.45(2 \mathrm{H}, \mathrm{s}, \mathrm{OH})$. Mass spectrum (ESI): Found, $m$ / z: $426.9[\mathrm{M}-2 \mathrm{H}]^{-} . \mathrm{C}_{25} \mathrm{H}_{14} \mathrm{O}_{7}$. Calculated, $m$ / z: 426.3 .

\section{3,3-(2-Chlorobenzylidene)-bis(4-hydroxy-2H-chromen-2- one) (3f)}

White crystalline solid, $\mathrm{mp} 196-198^{\circ} \mathrm{C}$. IR spectrum (KBr), $v / \mathrm{cm}^{-1}$ : 3072, 2981 (O-H), 1646, 1617 (C=O), 1564, 1496, $1451(\mathrm{C}=\mathrm{C}), 761(\mathrm{C}-\mathrm{H}), 641(\mathrm{C}-\mathrm{Cl}) .{ }^{1} \mathrm{H}$ NMR spectrum (400MHz, $\left.\mathrm{CDCl}_{3}\right), \delta / \mathrm{ppm}: 6.14(1 \mathrm{H}, \mathrm{s}, \mathrm{CH}) ; 7.21-8.03(12 \mathrm{H}$, $\mathrm{m}, \mathrm{H} \mathrm{Ar}) ; 10.93(1 \mathrm{H}, \mathrm{s}, \mathrm{OH}) ; 11.63(1 \mathrm{H}, \mathrm{s}, \mathrm{OH})$. Mass spectrum (ESI): Found, $m / z: 444.9[\mathrm{M}-2 \mathrm{H}]^{-} . \mathrm{C}_{25} \mathrm{H}_{13} \mathrm{ClO}_{6}$. Calculated, $m$ / $z$ : 444.8 .

\section{3,3-(3-Chlorobenzylidene)-bis(4-hydroxy-2H-chromen-2- one) (3g)}

White crystalline solid, $\mathrm{mp} 222-224^{\circ} \mathrm{C}$. IR spectrum (KBr), $v / \mathrm{cm}^{-1}$ : 3074, 3019 (O-H), 1658, 1617 (C=O), 1568, 1496, $1452(\mathrm{C}=\mathrm{C}), 761(\mathrm{C}-\mathrm{H}), 651(\mathrm{C}-\mathrm{Cl}) .{ }^{1} \mathrm{H}$ NMR spectrum (400MHz, $\left.\mathrm{CDCl}_{3}\right), \delta / \mathrm{ppm}: 6.04(1 \mathrm{H}, \mathrm{s}, \mathrm{CH}) ; 7.09-8.07(12 \mathrm{H}$, $\mathrm{m}, \mathrm{H} \mathrm{Ar}) ; 11.30(1 \mathrm{H}, \mathrm{s}, \mathrm{OH}) ; 11.57(1 \mathrm{H}, \mathrm{s}, \mathrm{OH})$. Mass spectrum (ESI): Found, $m$ / z: $444.9[\mathrm{M}-2 \mathrm{H}]^{-}$. $\mathrm{C}_{25} \mathrm{H}_{13} \mathrm{ClO}_{6}$. Calculated, $m$ / $z$ : 444.8 .

\section{Biochemical Assays}

\section{IN VITRO CELL PROLIFERATION ASSAY}

The performed cell proliferation (MTT) assay is based on the ability of mitochondrial succinate-tetrazolium reductase system to convert yellow tetrazolium salt MTT to purple formazan dye. Only cells which are alive possess active mitochondrial enzyme system and thus produce purple formazan from MTT. In this way, MTT assay is an index of cell viability. To evaluate the effect of coumarins and biscoumarins on the proliferation of A549 cells and to determine their sub-toxic concentrations, MTT assay was employed. Cell were seeded into a 96-well microtiter plate and different concentration of compounds dissolved in DMSO (500 $\mu \mathrm{M}, 250,125,62.5,31.25,15.62,7.81 \mu \mathrm{M})$ were sequentially added. Controls consisted of cells treated with DMSO (vehicle control). Each concentration was tested in triplicate. The cells were incubated at $37{ }^{\circ} \mathrm{C}$ in a humidified incubator with $5 \% \mathrm{CO}_{2}$ for $24 \mathrm{~h}$ followed by addition of MTT solution and incubation for $4 \mathrm{~h}$ at $37^{\circ} \mathrm{C}$ in dark. Then the supernatant was removed and an equal volume of DMSO was added to dissolve the formazan crystals. The absorbance was measured at $590 \mathrm{~nm}$ against background absorption at $650 \mathrm{~nm}$ in a microplate reader (EPOCH, Bio-Tek Instruments, USA).

\section{IN VITRO WOUND HEALING ASSAY}

The wound-healing assay is a simple, inexpensive and one of the best methods to study the cell migration in vitro. This assay is a mimetic of cell migration during wound healing in vivo and the methodology involves creating a wound in a cell monolayer, capturing images at the start of the assay and at regular intervals to the wound closure. In our experiments, A549 cells were grown to confluency in six well plates. The cell monolayer was then scratched with a 200 $\mu \mathrm{L}$ pipette tip, washed twice with PBS and photographed ( $t$ $=0 \mathrm{~h}$ ). Cells were then incubated in different less cytotoxic concentrations $(62.5 \mu \mathrm{M}, 31.25,15.62,7.81 \mu \mathrm{M})$ of biscoumarin for $24 \mathrm{~h}$ or left untreated. Then the wounds were observed and photographed ( $t=24 \mathrm{~h}$ ). The assay was repeated three independent times. The percentage of wound closure was estimated as described in our earlier work, using area covered by cells in a treatment group with respect to control to calculate the percentage wound closure. ${ }^{[36]}$

\section{IN VITRO INVASION ASSAY}

This assay measures the capacity of cell motility and invasiveness toward a chemo-attractant gradient. The invasion assay was performed using Matrigel coated polycarbonate filter inserts ( $8 \mu \mathrm{m}$ pore size, Corning). Cells suspended in DMEM were seeded onto membranes of the transwell inserts to which indicated less cytotoxic concentrations $(62.5 \mu \mathrm{M}, 31.25,15.62,7.81 \mu \mathrm{M})$ of 
biscoumarin were sequentially added. These inserts were then placed into the wells of 24-well plate containing DMEM supplemented with $10 \%$ fetal bovine serum (FBS) which served as a chemotactic agent. After $24 \mathrm{~h}$ incubation, the un-migrated cells in the upper chamber of the filters were removed by using a cotton swab. The cells that migrated and adhered to the other side of the membrane were fixed in $3.7 \%$ formaldehyde for 20 min followed by staining with crystal violet. The migrated cells were counted per five fields and the experiment was repeated at least for three independent experiments.

\section{CONCLUSION}

In conclusion, we have developed environmentally benign method for the synthesis of biscoumarins under catalyst free aqueous phase microwave irradiation condition using a microwave synthesizer. A comparative analysis of synthetic methodology under conventional refluxing, microwave irradiation conditions of a domestic and microwave reaction synthesizer has been reported. In addition to the increased yields and attenuated reaction times for biscoumarin synthesis, the difficulty of reaction control and result reproducibility usually encountered with domestic microwave ovens have been addressed through an optimized synthetic methodology using microwave synthesizer. Besides, the explanation of an important feature of solvent influence under microwave irradiation on the $\%$ yields of the seven synthetic reactions using $2: 1$ water-ethanol was arrived at by comparison of reaction under domestic and Anton Paar microwave synthesizer conditions. The effect of biscoumarin scaffold towards the anti-metastatic behavior of human lung carcinoma cell line has been investigated by in vitro migration and invasion assays, suggesting that biscoumarin scaffold inhibits the migration and invasion of lung carcinoma cells in a dose dependent manner and can thus be explored further towards advancements in cancer metastasis treatment.

Acknowledgment. SMB thanks Department of Science and Technology, New Delhi, India for INSPIRE fellowship. MAR thankfully acknowledges University of Kashmir for the financial assistance under innovative research scheme of UGC $12^{\text {th }}$ Plan.

\section{REFERENCES}

[1] I. Manolov, C. Maichle-Moessmer, N. D. Danchev, Eur. J. Med. Chem. 2006, 41, 882.

[2] C. C. Chiang, L. Y. Hsu, H. J. Tsai, C. W. Yao, T. C. Chang, Journal of CCIT. 2008, 37, 15.

[3] N. Hamdi, M. C. Puerta, P. Valerga, Eur. J. Med. Chem. 2008, 43, 2541.
[4] Z. H. Chohan, A. U. Shaikh, A. Rauf, C. T. Supuran, J. Enzym. Inhib. Med. Chem. 2006, 21, 741.

[5] D. Završnik, S. Muratović, D. Makuc, J. Plavec, M. Cetina, A. Nagl, E. D Clercq., J. Balzarini, M. Mintas, Molecules 2011, 16, 6023.

[6] J. Du, D. H. Daniels, C. Asbury, S. Venkataraman, J. Liu, D. R. Spitz, L. W. Oberley, J. J. Cullen, J. Biol. Chem. 2006, 281, 37416.

[7] I. Kostava, I. Manolov, I. Nicolova, S. Konstantonov, M. Karaivanova, Eur. J. Med. Chem. 2001, 36, 339.

[8] C. X. Su, J. F. Mouscadet, C. C. Chiang, H. J. Tsai, L. Y. Hsu, Chem. Pharm. Bull. 2006, 54, 682.

[9] C. C. Chiang, J. F. Mouscadet, H. J. Tsai, C. T. Liu, L. Y. Hsu, Chem. Pharm. Bull. 2007, 55, 1740.

[10] H. Madari, D. Panda, L. Wilson, R. S. Jacobs, Taxol, Cancer Res. 2003, 63, 1214.

[11] A. Lewis, M. Ough, L. Li, M. M. Hinkhouse, J. M. Ritchie, D. R. Spitz and J. J. Cullen, Clin. Cancer Res. 2004, 10, 4550.

[12] H. Hagiwara, S. Miya, T. Suzuki, M. Ando, I. Yamamoto, M. Kato, Heterocycles 1999, 51, 493.

[13] M. M. Heravi, S. Sadjadi, N. M. Haj, H. Oskooie, F. F. Bamoharram, Catal. Commun. 2009, 10, 1643.

[14] A. Davoodnia, Bull. Korean Chem. Soc. 2011, 32, 4286.

[15] V. Padalkar, K. Phatangare, S. Takale, R. Pisal, A. Chaskar, J. Saudi Chem. Soc. 2015, 19, 42.

[16] M. M. Heravi, F. Nahavandi, S. Sadjadi, H. Oskooie, F. Bamoharram, Synth. Commun. 2010, 40, 498.

[17] J. M. Khurana, K. Vij, J. Chem. Sci. 2012, 124, 907.

[18] H. Hagiwara, N. Fujimoto, T. Suzuki, M. Ando, Heterocycles 2000, 53, 549.

[19] H. R. Shaterian, M. Honarmand, Chin. J. Chem. 2009, 27, 1795.

[20] G. Cravotto, G. M. Nano, G. Palmisano, S. Tagliapietra, Synthesis 2003, 8, 1286.

[21] M. Kidwai, V. Bansal, P. Mothsra, S. Saxena, R. K. Somvanshi, S. Dey, T. P. Singh, J. Mol.Catal. A: Chem. 2007, 268, 76.

[22] J. M. Khurana, S. Kumar, Tetrahedron Lett. 2009, 50, 4125.

[23] H. Mehrabi and H. Abusaidi, Journal of the Iranian Chemical Society. 2010, 7, 890.

[24] P. Singh, P. Kumar, A. Katyal, Catal. Lett. 2010, 134, 303.

[25] Z. N. Siddiqui, F. Farooq, Catal. Sci. Technol. 2011, 1, 810.

[26] S. Qadir, A. A. Dar, K. Z. Khan, Synthetic Commun. 2008, 38, 3490.

[27] R. Deshidi, M. A. Rizvi, B. A. Shah, RSC Advances 2015, 5, 90521.

[28] S. Devari, M. Kumar, R. Deshidi, M. Rizvi, B. A. Shah, Beilstein J. Org. Chem. 2014, 10, 2649. 
[29] S. Devari, R. Deshidi, M. Kumar, A. Kumar, S. Sharma, M. Rizvi, M. Kushwaha, A. P. Gupta, B. A. Shah, Tetrahedron Lett. 2013, 54, 6407.

[30] M. Kumar, A. Kumar, M. Rizvi, M. Mane, K. Vanka, S. C. Taneja, B. A. Shah, Eur. J. Org. Chem. 2014, 2014, 5247.

[31] S. Devari, M. A. Rizvi, B. A. Shah, Tetrahedron Lett. 2016, 57, 3294.

[32] D. Dallinger, C. O. Kappe, Chem. Rev. 2007, 107, 2563.

[33] F. Kormin, N. H. Abdurahman, R. M. Yunus, M. Rivai,
International Journal of Engineering Science and Innovative Technology, 2013, 2, 417.

[34] M. P. Gleeson, J. Med. Chem. 2008, 51, 817.

[35] H. K. Keerthy, C. D. Mohan , K. S. Sivaraman, J. E. Fuchs , S. Rangappa, M. S. Sundaram, F. Li , K. S. Girish, G. Sethi, B. A. Basappa, K. S. Rangappa, J Biol Chem. 2014, 289, 31879.

[36] A. Amin, N. A. Chikan, T. A. Mokhdomi, S. Bukhari, A. M. Koul, B. A. Shah, F. R. Gharemirshamlu, A. H. Wafai, A. Qadri, R. A. Qadri, Sci. Rep. 2016, 6, 37151. 